Santa Clara University

Scholar Commons

Economics

Leavey School of Business

$5-26-2018$

\title{
The rapid evolution of homo economicus: Brief exposure to neoclassical assumptions increases self- interested behavior
}

John Ifcher

Santa Clara University, jifcher@scu.edu

Homa Zarghamee

Follow this and additional works at: https://scholarcommons.scu.edu/econ

Part of the Economics Commons

\section{Recommended Citation}

Ifcher, J., \& Zarghamee, H. (2018). The rapid evolution of homo economicus: Brief exposure to neoclassical assumptions increases self-interested behavior. Journal of Behavioral and Experimental Economics, 75, 55-65. https://doi.org/10.1016/j.socec.2018.04.012

(C) 2018. This manuscript version is made available under the CC-BY-NC-ND 4.0 license http://creativecommons.org/licenses/by-nc-nd/4.0/

https://doi.org/10.1016/j.socec.2018.04.012

This Article is brought to you for free and open access by the Leavey School of Business at Scholar Commons. It has been accepted for inclusion in

Economics by an authorized administrator of Scholar Commons. For more information, please contact rscroggin@scu.edu. 
elThe Rapid Evolution of Homo Economicus:

Brief Exposure to Neoclassical Assumptions Increases Self-Interested Behavior

\author{
John Ifcher \\ Santa Clara University \\ (408) 554-5579 \\ jifcher@scu.edu \\ Corresponding author: \\ Homa Zarghamee \\ Barnard College \\ 3009 Broadway \\ New York, NY 10027 \\ (212) 854-8946 \\ hzargham@barnard.edu
}

JEL Codes: A2, D6, C9, C7, A1

Keywords: Economics instruction, Self-interest, Game theory, Laboratory experiment, Social preferences

\begin{abstract}
Economics students have been shown to exhibit more selfishness than other students. Because the literature identifies the impact of long-term exposure to economics instruction (e.g., taking a course), it cannot isolate the specific course content responsible; nor can selection, peer effects, or other confounds be properly controlled for. In a laboratory experiment, we use a within- and across-subject design to identify the impact of brief, randomly-assigned economics lessons on behavior in the ultimatum game (UG), dictator game (DG), prisoner's dilemma (PD), and publicgoods game (PGG). We find that a brief lesson that includes the assumptions of self-interest and strategic considerations moves behavior toward traditional economic rationality in UG, PD, and DG. Despite entering the study with higher levels of selfishness than others, subjects with prior exposure to economics instruction have similar training effects. We show that the lesson reduces efficiency and increases inequity in the UG. The results demonstrate that even brief exposure to commonplace neoclassical economics assumptions measurably moves behavior toward selfinterest.
\end{abstract}




\section{Introduction}

There is reason to believe that components of economics instruction may have unintended consequences: compared to other students, economics students are more likely to act in their own self-interest, are (and believe others to be) less honest, and view greed more favorably. There is evidence of both selection and training effects. Training effects are concerning given that approximately $40 \%$ of undergraduates take at least one economics course (Siegfried \& Walstad, 2014); and the most popular major in the U.S. is business, which requires economics coursework (Snyder et al., 2016).

A limitation of the existing training-effect literature is that it identifies the impact of long-term exposure to economics instruction and cannot isolate the specific content causing the impact; nor can selection, peer effects, or other confounds be properly controlled for. We attempt to address these shortcomings by testing the impact of economics instruction on selfishness with the control afforded by a laboratory experiment. Specifically, we use a within- and across-subject design to identify the impact of brief, randomly-assigned economics lessons on behavior in the ultimatum game (UG), dictator game (DG), prisoner's dilemma (PD), and public-goods game (PGG).

We find that a brief lesson that includes the assumption of self-interest and strategic considerations moves behavior toward traditional economic rationality in the UG, PD, and DG. The impact of the lesson is at least as strong for subjects with prior exposure to economics instruction as for those without, despite the former entering the study with higher levels of selfishness than the latter. Lastly, we show that the lesson reduces efficiency and increases subject-payment inequality in the UG. The results demonstrate that brief exposure to commonplace neoclassical economics assumptions measurably moves behavior toward selfinterest.

\section{Literature Review}


Individuals exposed to economics instruction - economists, economics majors, and even undergraduates who take a single economics course ${ }^{1}$ - appear to have different attitudes and behaviors vis-a-vis selfishness than those not exposed. Economics students behave more in accordance with traditional economic rationality in games (PGG: Marwell \& Ames, 1981; UG: Carter \& Irons, 1991; PD: Frank et al., 1993); give less to charity (Bauman \& Rose, 2011; Frank et al., 1993; Frey \& Meier, 2003); exhibit less honesty (Frank et al., 1993; Frank \& Schulze, 2000); view greed more favorably (Wang et al., 2011); and place greater importance on individualism than collectivism (Gandal et al., 2005). To our knowledge, only one study presents contravening evidence: Yezer et al. (1996) find that "lost envelopes" containing money are more likely to be mailed to the addressee if left in economics classes than other classes.

The bulk of the literature compares economics students to other students. As such, identification relies on the effects of long-term exposure to economics instruction (e.g., semester-long courses or entire majors). For example, a seminal study finds that economics Ph.D. students contribute less in the PGG than do other students (Marwell \& Ames, 1981). This approach has several weaknesses: it cannot distinguish between selection and training effects; training effects may be confounded with factors unrelated to instructional content (e.g., classmates and professors); and if there are training effects, the specific course content responsible cannot be identified.

Some of these concerns have been addressed better than others. A number of studies use a within-subject design whereby selection effects are identified using differences between the behavior of economics and other students at the start of their economics education, and training effects are identified using pre- to post-education differences in the behavior of economics versus other students. Bauman \& Rose (2011) find evidence of selection effects in charitable donations. They also find evidence of training effects over a three-year period among students who have taken economics courses but do not major in economics, and no evidence of training effects for economics majors. Frank et al. (1993) find evidence of selection effects in PD defection-rates. They also find evidence of training effects using honesty-surveys for students in an introductory economics course as compared to introductory astronomy. Frey \& Meier (2003)

\footnotetext{
${ }^{1}$ Hereafter we will use "economics students" to refer to all three groups.
} 
find evidence of selection-effects in charitable donations; they find no evidence of training effects.

It is important to note that Bauman \& Rose (2011) and Frank et al. (1993) cannot rule out that their training effects are due to selection-effects insofar as students selecting into economics instruction are more susceptible to its selfishness-promoting content. Further, studies using longterm exposure to economics instruction cannot distinguish between the impact of instruction and other factors. Economics students may be invited to join a business fraternity, or economics instruction may pique students' interest in financial markets, leading them to learn about, and invest in, stocks; in other words, extracurricular activities may explain what are identified as training effects.

Lastly, studies using long-term exposure to economics instruction cannot identify, from among the many topics covered, the specific course content responsible for training effects. Frank et al. (1993) find a greater training effect in an introductory microeconomics course taught by an instructor with a game-theoretic orientation than in the same course taught by an instructor with a Maoist/development orientation. As the courses were very similar in content, this suggests that training effects are affected by characteristics beyond the syllabus, like professors' choice of emphasis and examples, or selection of students into courses taught by different professors.

\section{Experimental Design}

We conducted a laboratory experiment to test the impact of brief economics lessons on selfishness. The experimental design allowed for both within- and across-subject comparisons: each subject completed the experimental tasks before and after treatment, and treatment was randomly assigned across subjects. All tasks were incentivized.

The experiment was conducted at Santa Clara University (SCU) in the winter and spring quarters of 2016. 276 students participated. In an attempt to ensure that the sample was representative of the undergraduate student body, we emailed all first- and second-year students inviting them to participate. Prospective subjects were told that participation in the study would take about 60 
minutes and that they would be paid for their participation, with a minimum, average, and maximum payment of $\$ 5, \$ 20$, and $\$ 40$. Sessions lasted approximately 60 minutes, and subjects received a minimum, average, and maximum payment of $\$ 5.00, \$ 18.75$, and $\$ 45.75$. The experiment was conducted in a classroom equipped with downview computer-desks using z-Tree (Fischbacher, 2007); screenshots are included in Appendix A. In brief, our experimental procedure was as follows (additional details provided below).

- Subjects read and signed the informed consent form.

- Subjects read instructions and were given the opportunity to make a real charitable donation.

- Subjects completed Tasks 1-6 (randomly ordered): UG (as proposer and responder), DG (as dictator and recipient), PGG, and PD. Subjects were not yet provided feedback about the tasks' outcomes.

- Subjects received a brief, randomly-assigned economics lesson

- Subjects completed Tasks 7-12, a randomly-ordered repetition of Tasks 1-6. Subjects were not yet provided feedback about the tasks' outcomes.

- Subjects' risk preferences were elicited (Task 13).

- The payment task was randomly chosen from Tasks 1-13. Subjects learned the payment task's outcome.

- Subjects completed a questionnaire that included demographic and other items.

- Subjects received their payments and exited the session.

\subsection{Real charitable donation opportunity}

Subjects were informed that they were starting with $\$ 5$ and could donate between $\$ 0$ and $\$ 5$ to the Santa Clara Fund. This exercise was intended to familiarize subjects with the z-Tree program, to give subjects a sense of the decisions they would be making, and to measure subjects' baseline willingness to donate to a charity. Subjects were given the following information from the Santa Clara Fund website: "The Santa Clara Fund supports four areas of campus that are distinguishing factors of a Jesuit education: $60 \%$ is awarded as scholarships; $20 \%$ supports academic programs; $15 \%$ is awarded to help students travel abroad and participate 
in immersion trips; and 5\% is available for student clubs and initiatives. One hundred percent of the gifts made to this fund serve SCU students."

\subsection{Tasks $1-6$}

Tasks 1 and 2 involved a standard UG. Subjects were informed that a "proposer" who had been endowed with $\$ 20$ would make an "offer" between $\$ 1$ and $\$ 20$ to a "responder." If the responder accepted the offer, then the proposer's payment would be $\$ 20$ minus the offer and the responder would receive the offer. In contrast, if the responder rejected the offer, then both the proposer and responder would receive $\$ 0$. Subjects were informed that they would play twice, once as proposer (Task 1) and once as responder (Task 2) and that they would be randomly matched with a subject in the session each time they played.

Tasks 3 and 4 involved a standard DG. Subjects were informed that a "divider" who had been endowed with $\$ 20$ would choose how to divide her $\$ 20$ endowment with a "recipient;" divisions could be between $\$ 0$ and $\$ 20$. Subjects were informed that they would play twice, once as divider (Task 3) and once as recipient (Task 4). Further, subjects were informed that they would be randomly matched with a subject in the session each time they played.

Task 5 was a standard PGG. Subjects were informed that they had each been endowed with $\$ 20$ and would choose how much of this endowment to allocate to the "4-person pile" (a public investment) with three other randomly selected subjects. All allocations to the 4-person pile were multiplied by 1.5 and divided evenly among the four subjects. Each subject's payment in Task 5 was the sum of what she did not allocate to the 4-person pile plus a quarter of the 4person pile.

Task 6 was a standard PD. Subjects were informed that they would be randomly matched with another subject to play the "the box game" in which they would each choose between "Option A" (cooperate in the standard PD) and "Option B" (defect in the standard PD); they were shown a "box" (a standard PD payoff matrix) with diagonal payoffs of (\$10, \$10) and $(\$ 5, \$ 5)$ and offdiagonal payoffs of $(\$ 0, \$ 20)$ and $(\$ 20, \$ 0)$. 
The UG, DG, PGG, and PD were chosen to represent a range of experimental games that are commonly used to measure other-regarding preferences. The order of the games was randomized by subject. For UG (DG), the order of Tasks 1 (3) and 2 (4) was randomized as well. Subjects answered two unincentivized items testing their comprehension after instructions and before playing each game. In an attempt to decontextualize the games, we referred to them as follows: the UG was called the "Offer Game," the DG was called the "Division Game," the PGG was called the "Four-Person Pile Game," and the PD was called the "Box Game." Finally, subjects received no feedback regarding the outcome of the games until the end of the session. The random matching of players in each task and lack of feedback were intended to reduce the scope for reciprocity and learning.

\subsection{Brief, randomly-assigned economics lessons}

Subjects read one of three randomly-assigned lessons about game theory: normative, positive, or control. Each lesson started with the corresponding paragraph below.

- Normative: "HOW TO PLAY GAMES SUCH AS THOSE YOU JUST PLAYED. Normative economics helps economists understand how individuals should make decisions in games such as those you just played. To make normative economic assertions, economists build economic models. In such models, economists make the following assumptions: (1) that all individuals are self-interested and (2) that all individuals attempt to maximize their payments. Further, economists examine all the strategies available to an individual to determine which one maximizes his or her payment. Economists do this by working backward. First, economists consider all the choices the individual's opponent could make, and then, determine the choice that maximizes the individual's payment. Now we will apply normative economic analysis to the Box Game and the Offer Game to see what we can learn."

- Positive: "HOW TO PLAY GAMES SUCH AS THOSE YOU JUST PLAYED. Positive economics helps economists understand how individuals actually make decisions in 
games such as those you just played. To make positive economic assertions, economists can conduct laboratory experiments. In such experiments, economists recruit groups of people to play games like you just played. Further, economists record and examine the choices people make to learn how people play the games. They do this by building analytical databases and using statistical analyses. From such analyses, economists can determine what percentage of the people choose Option A or Option B in the Box Game; what the average offer is in the Offer Game; and how much a proposer has to offer, on average, in the Offer Game so that most responders (for example, more than 75\%) accept the offer. Now we will apply positive economic analysis to the Box Game and the Offer Game to see what we can learn."

- Control: "HOW TO DESIGN GAMES SUCH AS THOSE YOU JUST PLAYED. Game theory helps economists understand strategic interactions. To design a game, that is, model a strategic interaction, economists must specify the number of players, the actions available for each player at each decision point, and the payment for each outcome. Games in which decisions are made concurrently are generally represented using a "normal form," the Box Game is such a game. Games in which decisions are made sequentially can be represented using an "extensive form," the Offer Game is such a game. Now we will discuss how the Box Game and the Offer Game are represented using game theory."

In order to cleanly identify the specific lesson-content that impacts behavior, the lessons were carefully designed to be parallel in structure and to mirror standard economics textbook styles (e.g., Dutta (1999); Mankiw (2015); Frank et al. (2015); Krugman \& Wells (2015)). The "normative" lesson was designed to relay the economic model of how games are played and to include content that we believe may contribute to training effects in economics instruction: the assumption of own-payoff maximization and an explanation of strategic considerations. The primary goal of this study is to identify the impact of the normative lesson. As introductory economics instruction usually distinguishes between normative and positive analysis early on, we also consider the impact of a "positive" lesson: subjects are informed of average behavior in economics games from the empirical experimental literature. A "control" lesson describes how 
games are designed with no normative or positive content. We chose the economics lessons to be about game theory for several reasons. It was important that the lessons be brief, thorough, and self-contained, given the time constraints inherent to laboratory experimentation. To minimize confounds, it was important that the lessons be on topics about which subjects had few preconceived notions, experience, or political opinion. Lessons about game theory seemed a natural fit.

Each of the three lessons also included an application of the corresponding paragraph above to the UG and PD. For example, in the normative lesson's UG-illustration, subjects read: "notice that if the responder accepts the offer, his or her payment will be greater than if he or she rejects the offer regardless of the proposer's offer... Thus, accepting the offer is the dominant strategy for the responder..." In the positive lesson's UG-illustration, subjects read: "The experiment was conducted at University of British Columbia... [P] roposers, on average, offered about 45\% of the money they started the experiment with (to the responder)..." (See Appendix A for the complete lessons). Subjects answered two unincentivized items testing their comprehension of the UG- and PG-applications.

The decision not to include applications of the DG and PGG enables the identification of spillovers, ensuring that subsequent behavior is due to lesson-content and not replication of the application. The normative lesson's UG- and PD-applications include both the assumption of self-interest and strategic considerations. The DG does not involve strategic considerations, so if behavior in the DG is affected by the normative lesson, it is presumably due to the assumption of self-interest. Behavior in the PGG can be affected by both the assumption of self-interest and strategic considerations. Finally, if behavior in the UG or PD is affected by the normative lesson, it could be due to the assumption of self-interest, strategic considerations, or replication of the application.

To reduce experimenter demand effects, interaction with the experimenter was minimized: all lessons were presented on individual computer screens with no audio, video, or lecture components. This also allowed for within-session randomization of the treatment, eliminating the confounding of treatment- and session-effects and ensuring that experimenter interactions were 
identical across the three treatments. While we sought to minimize experimenter demand effects, one of the ways in which economics instruction may impact behavior in its natural setting is through the existence of analogous "instructor demand effects." The use of a laboratory setting may not give rise to the usual external-validity critiques because the natural setting of economics instruction is similarly within university classrooms.

\subsection{Tasks $7-12$}

In Tasks 7-12, subjects repeat Tasks 1-6; the order of games and player-matching were randomized again. Subjects received abbreviated instructions, were not tested for comprehension, and again received no feedback regarding the tasks' outcomes.

\subsection{Task 13}

Subjects' risk preferences were elicited using a 21-item multiple-price list in which subjects chose between a fixed payment $(\$ 0-\$ 20)$ and a lottery with even odds of receiving a $\$ 0$ or $\$ 20$ payment.

\subsection{Questionnaire}

Subjects completed a questionnaire that included items regarding their demographic and other characteristics. The questionnaire included an abbreviated 10-item version of the Narcissism Personality Inventory (NPI) and nine items from Konow (2003) on attitudes toward justice.

\subsection{Payments}

Subjects were given detailed information regarding the calculation of payments. One of Tasks 113 was randomly chosen for payment. If Task 13 was chosen, then one of the 21 fixed payments was randomly chosen and the lottery was implemented. All randomization was implemented using a bingo spinner. Total subject-payments were the sum of the $\$ 5$ show-up fee, the portion of the $\$ 5$ not donated to the Santa Clara Fund, and the payment-task. Subjects were paid in cash. 
The payment was placed in an envelope with only the subjects' identification number on it. Subjects received their payment as they exited the session. Payments were double blind: one administrator prepared the envelopes, and another distributed them.

\section{Results}

We present the results by first comparing behavior in the normative, and then the positive, treatment to the control. For each comparison, we first consider behavior in the games used to illustrate the lessons (UG and PD), and then consider evidence of spillover effects (DG and PGG).

\subsection{Normative treatment versus control}

\subsubsection{UG}

Tables $1 \& 2$ and Figure 1 present evidence of training effects in the UG, with both proposers and responders behaving more in accordance with traditional economic rationality after the normative treatment than after control. While normative-treatment and control pre-lesson mean offers are statistically indistinguishable, normative-treatment post-lesson mean offers are significantly lower than in control; the same pattern holds for minimum accepted offers. ${ }^{2}$ Comparing pre- to post-lesson behavior, normative-treatment proposers reduce their offers by significantly more than control proposers: 46\% (\$4.06/\$8.76) versus $7 \%(\$ 0.61 / \$ 8.37)$. Normative-treatment responders reduce their minimum accepted offers by significantly more than control responders: $43 \%(\$ 1.90 / \$ 4.37)$ versus $15 \%(\$ 0.72 / \$ 4.69)$. The proportions of normative-treatment proposers reducing their offers and responders reducing their minimum accepted offers are significantly greater than control. Further, the proportion of normativetreatment proposers increasing their offers is almost zero and is significantly lower than control,

\footnotetext{
2 The strategy method was used to elicit responses to all possible offers. A subject's minimum accepted offer corresponds to the dollar value such that it and greater offers are accepted and lesser offers are rejected. For 13 subjects, their pre- or post-lesson responses do not follow a pattern that allows for identification of a minimum accepted offer ( 6 in normative, 2 in positive, and 5 in control). Some subjects have multiple switch points, while others accept low and reject high offers. Subjects with ambiguous Task-2 or -7 minimum accepted offers are dropped from all analyses that use minimum accepted offers as the dependent variable.
} 
while the proportions of control proposers decreasing and increasing their offers are statistically indistinguishable. All results are similar when we restrict to subjects who correctly answer the UG-comprehension-questions.

\subsubsection{PD}

Table 3 presents evidence of training effects in the PD, with subjects behaving more in accordance with traditional economic rationality after the normative treatment than after control. While mean defection rates are statistically indistinguishable for the normative treatment and control in both pre- and post-lesson comparisons, the defection rate in the normative treatment increases by marginally significantly more than in control: $39 \%(0.23 / 0.59)$ versus $17 \%$ $(0.11 / 0.63)$. The results become fully significant when we restrict to subjects who correctly answer the PD-comprehension-questions.

\subsubsection{DG}

Table 4 presents evidence of training effects in the DG, with subjects behaving more in accordance with traditional economic rationality after the normative treatment than after control. While normative-treatment and control pre-lesson mean offers are statistically indistinguishable, normative-treatment post-lesson mean offers are significantly lower than in control. Comparing pre- to post-lesson behavior, normative-treatment dictators reduce their offers by significantly more than control dictators: $36 \%(\$ 1.78 / \$ 4.89)$ versus $7 \%(\$ 0.35 / \$ 5.07)$. The proportion of normative-treatment dictators reducing their offers is significantly greater than control. The proportions of control dictators decreasing and increasing their offers are statistically indistinguishable. All results are similar when we restrict to subjects who correctly answer the DG-comprehension-questions.

\subsubsection{PGG}

Table 5 presents PGG behavior in the normative treatment and control. There is no evidence of training effects in the PGG using either across- or within-subject comparisons. The only 
exception is when we restrict to subjects who correctly answer the PGG-comprehension questions: contributions to the public investment are reduced by marginally more in the normative treatment than in control: $15 \%(\$ 1.05 / \$ 6.99)$ versus $1 \%(\$ 0.09 / \$ 6.83)$.

\subsection{Positive treatment versus control}

We find almost no evidence of positive-treatment training effects (see Tables 6-10). The few statistically significant differences that emerge suggest that subjects' post-lesson behavior is less in accordance with traditional economic rationality in the positive treatment than control. In the UG, positive-treatment responders increase their minimum accepted offers by $4 \%(\$ 0.17 / \$ 4.03)$, while control responders decrease their minimum accepted offers by $15 \%(\$ 0.72 / \$ 4.69)$; the proportion of UG-responders whose minimum accepted offers increase is higher in the positive treatment than control (see Table 7). The proportion of subjects whose PGG-contributions increase is marginally higher in the positive treatment than in control (see Table 10). The absence of positive-treatment training effects is perhaps unsurprising as the brief lesson relayed the behavior of student subjects who likely behave similarly to SCU subjects.

\subsection{Subgroups}

Below we present the results of subgroup analyses by prior exposure to economics instruction, donations to the SCU Fund, and NPI score. We also conduct subgroup analyses by gender, family income, and quiz score and find no systematic differences; results not reported. ${ }^{3}$

\subsubsection{Prior exposure to economics instruction}

In the questionnaire, subjects are asked if they have ever studied game theory in any course. Of 276 subjects, 72 answer affirmatively. Comparing the pre-lesson behavior of these subjects to

\footnotetext{
3 In the questionnaire, subjects are asked to report their family's annual income on a nine-item response scale: Under \$20,000; \$20,00-\$40,000; \$40,000-\$60,000; \$60,000-\$80,000; \$80,000-\$100,000; \$100,000-\$150,000; $\$ 150,000-\$ 200,000 ; \$ 200,000-\$ 500,000$; Over $\$ 500,000$. The median response was $\$ 100,000-\$ 150,000$. The lowincome (high-income) subgroup included subjects who reported income below $\$ 100,000$ (above $\$ 150,000$ ). Each subject answered a total of 12 quiz questions. The median number of correct answers was 11. The low (high) quizscore subgroup included subjects who got less than (more than) 11 correct answers.
} 
the rest reveals a similar pattern to our normative-treatment training effects. Specifically, subjects who have studied game theory behave more in accordance with traditional economic rationality in the $\mathrm{UG}, \mathrm{PD}$, and DG; behavior in the PGG is statistically indistinguishable (see Table 11). Contributions to the SCU Fund are marginally lower for subjects who have studied game theory.

Subjects are also asked if they have taken an SCU economics course; 100 answer affirmatively. ${ }^{4}$ Comparing the pre-lesson behavior of these subjects to the rest reveals that subjects who have taken an SCU economics course behave more in accordance with traditional economic rationality in the PD, DG, and PGG; behavior in the UG is statistically indistinguishable (see Table 12). Contributions to the SCU Fund are significantly lower for subjects who have taken an SCU economics course. For both prior exposure to game theory and SCU economics courses, the above pre-lesson differences could be explained by either training or selection effects.

To examine whether prior exposure to economics instruction might dampen the normativetreatment training effects, we restrict the sample to normative-treatment subjects. We pool subjects who have studied game theory or taken an SCU economics course and compare their behavior to the rest. We find that they are no less impacted by the normative treatment, except that, among UG responders, normative-treatment training effects are larger for subjects with prior exposure to economics instruction than the rest (see Table 13). ${ }^{5}$ The post-lesson behavior of those with prior exposure to economics instruction is more in accordance with traditional economic rationality in the UG (responder), PD, and DG. In the UG (proposer), the difference is marginally significant, and there is no difference in PGG.

\subsubsection{Donations to the SCU Fund}

Comparing the pre-lesson behavior of low-donation $(\$ 0)$ to high-donation (\$2-5) subjects reveals that the former behave more in accordance with traditional economic rationality than the latter in

\footnotetext{
${ }^{4}$ Having taken an SCU economics course is likely correlated with being an economics major or a student in the business school, as SCU's business school requires that undergraduates take multiple economics courses.

${ }^{5}$ It is also true that subjects with prior exposure to economics instruction are no more or less impacted by the positive treatment than are subjects without prior exposure.
} 
the UG (proposers only), PD, DG, and PGG; behavior in the UG (responders only) is statistically indistinguishable (see Table 14, mean and median donations are \$1.40 and \$1.00). There is some evidence that the normative treatment has a smaller impact on low- than high-donation subjects; the former decrease their offers by significantly less in the DG, and marginally less in UG (proposers only). Subgroup analysis by low- versus high-donation is of interest because (1) pre-lesson behavior in the UG (proposer only), PD, DG, and PGG is correlated to behavior in a real charitable decision, and (2) the normative treatment is more impactful for those who initially behave more charitably.

\subsubsection{NPI}

We include a 10-item subset of the 40-item NPI, which is used by social psychologists to measure narcissism (Raskin \& Hall, 1979). The American Psychiatric Association defines narcissism as a "a pervasive pattern of grandiosity (in fantasy or behavior), need for admiration, and lack of empathy (APA, 1994)," and it has been linked to increased cheating (Von Hippel et al., 2005), romantic infidelity (Campbell \& Foster, 2002), materialism, and impulsiveness (Rose, 2007). Possible scores on our 10-item NPI are integer values from 0 (least narcissistic) to 10 (most narcissistic). The median score in our sample is 3.

Comparing the pre-lesson behavior of low- (0-2) and high-narcissism (4-10) subjects reveals that the latter behave more in accordance with traditional economic rationality in the UG (proposers only) and PD, and contribute significantly less to the SCU fund; behavior in other games is statistically indistinguishable (see Table 15). The normative-treatment training effects are statistically indistinguishable for low- and high-narcissism subjects, except that normativetreatment training effects are marginally lower for the former in the PD.

\subsection{Efficiency and equity: an illustration}

We consider the impact of the normative treatment on efficiency and equity in Tasks 1 and 7 (pre- and post-lesson UG played as proposer). To measure efficiency, we use the proportion of the maximum possible social surplus that is realized (i.e., total subject payments divided by total 
possible subject payments within a task). This corresponds to the proportion of offers that are accepted in the UG, as accepted offers always generate \$20 in social surplus and rejected offers always generate $\$ 0$. Equity is measured by the Gini index of subject payments within a task. For each lesson-task pair, we create an "economy" that includes the proposers who receive the lesson and the responders with whom they are randomly matched, regardless of the lesson received by the responder.

Though there is no evidence of pre-lesson efficiency differences in Task 7, Table 16 shows that the normative lesson significantly reduces efficiency. The proportion of accepted offers decreases significantly more in the normative treatment than control: $20 \%(0.16 / 0.82)$ versus $2 \%$ $(0.02 / 0.87)$. Responders entirely bear the burden of the efficiency loss on average: normativetreatment responders are paid roughly half as much as their control counterparts, while mean proposer payments are statistically indistinguishable. Though normative-treatment proposers are more likely to receive a zero payment, their non-zero payments are larger than in control. Further, the evidence suggests that the normative lesson reduces equity. While pre-lesson Gini indexes are statistically indistinguishable, the post-lesson normative-treatment Gini index is significantly greater than in control. ${ }^{6}$ Figure 2 depicts the corresponding Lorenz curves.

\section{Discussion}

In a laboratory experiment, we demonstrate that a brief normative-economics lesson moves behavior toward traditional economic rationality and, in some settings, reduces both efficiency and equity. Our experiment enables the identification of specific content that may contribute to the behavior that economics students have exhibited in the literature. Specifically, the normative lesson relays the assumptions of self-interest and strategic considerations. It does so without mention of traditional economic theory stipulating that self-interest leads to efficiency; as such, the lesson's impact should not be attributable to the belief that acting in one's self-interest will lead to the greater good. Thus, the theory that self-interest leads to efficiency is not necessary to make subjects more selfish. Further, in the UG (as responder) and DG, strategic considerations should be irrelevant, as decisions are made in the absence of simultaneous or subsequent

\footnotetext{
${ }^{6}$ Standard errors are calculated using bootstrapping (100 repetitions).
} 
decisions by other players; still we observe normative-treatment training effects, indicating that the assumption of self-interest is sufficient and strategic considerations (and beliefs about others' behavior) are not necessary.

Why PGG public-investments are statistically indistinguishable in the normative- and controltreatments, though, is unclear. One possible explanation is that there are normative-treatment training effects that we do not have statistical power to identify. Supportive of this explanation is that normative-treatment subjects reduce their public investments more than control subjects; further, the magnitude of this difference increases and becomes marginally significant when we drop subjects who incorrectly answer PGG-comprehension questions. Another possible explanation is that the PGG has four players, and it may not be clear how to apply the normative lesson in this context. An interesting finding is that subjects who have taken SCU economics courses have significantly lower pre-lesson PGG investments than those who have not, but the same is not true for those who have been exposed to game theory. This may suggest that it is the economic characterization of the free-rider dilemma in economics courses that would reduce public investments rather than a game-theoretic lesson. Evidence that supports this explanation is that the difference in SCU-fund contributions of subjects who have and have not taken SCU economics courses is two times greater than the corresponding differences for those who have and have not been exposed to game-theory.

Future research is necessary to better understand the PGG-results and, more generally, to answer three important questions raised by this study. First, how long-lasting are normative-treatment training effects? This is important not just within our experiment, but also to understand how the effects of individual lessons and repetitions of specific assumptions are compounded over time. None of the existing literature has studied whether training effects last after graduation or shape their subsequent worldview. Second, what is the mechanism by which training effects are generated (e.g., priming, learning, perceived social norms)? Third, if economics instruction does indeed change students' behavior, how can we reframe economics lessons in a way that mitigates training effects? 
To understand potential policy implications of the current research, we speculate below about the second and third questions. We believe that introductory economics instruction often relegates to "fine print" the nuances of the assumptions, definitions, and limitations necessary to contextualize theoretical predictions. If students fail to understand or consider the fine print, it is conceivable that they might come to conclusions like the following: people are motivated by nothing but self-interest, people acting in their own self-interest generate efficient outcomes, perfectly competitive markets are the norm, efficiency should be privileged over other concerns, and redistribution is always inefficient. As such, they may fail to recognize collective-action problems or that self-interest does not lead to their efficient resolution. Further, students may not keep in mind the distinction between the technical economic definition of efficiency and its everyday usage as an unqualified good (e.g., the Dictionary.com definition of efficient is "performing or functioning in the best possible manner with the least waste of time and effort...”). Individuals with equity-concerns, for example, may then understand efficiency to imply a fair distribution of resources.

Another potential implication of the current study is that instructors should be aware that their authority in the pedagogic relationship may influence students' interpretation of lessons. An important critique of laboratory experimentation leveled by economists is that of experimenter demand effects, whereby subjects behave in accordance with what they believe to be the demands of the authoritative experimenter. Although the scope for such effects certainly exists in the classroom, no such critique has been leveled at analogous "instructor demand effects." We believe that instructor demand effects may bias students toward understanding assumptions-e.g., self-interest--as prescriptive or axiomatic. To minimize the possibility of such misunderstandings, instructors could, for example, explain that assumptions may be violated and provide illustrations. Further, instructors could thoroughly discuss theoretical ramifications of assumption-violation and highlight the distinction between model-based theoretical predictions and real-world phenomena.

More broadly, economics students may take the model of narrow self-interest they have learned and attempt to apply it in their everyday activities, at work, or in the voting booth. In a period of rapid population growth, resource-intensive lifestyles, and increasingly 
conspicuous climate change, it is all the more important that students leave the classroom with a balanced notion of self-interest that better aligns with the resolution of collective-action problems. We believe it is incumbent on the profession to consider how it can help ameliorate such problems.

References:

American Psychiatric Association (1994). Diagnostic and Statistical Manual of Mental Disorders, 4th ed. Washington, DC: Author.

Bauman, Y., \& Rose, E. (2011). Selection or indoctrination: Why do economics students donate less than the rest? Journal of Economic Behavior \& Organization, 79(3): 318-327.

Campbell, W.K., \& Foster, C.A. (2002). Narcissism and commitment in romantic relationships: An investment model analysis. Personality and Social Psychology Bulletin, 28(4): 484-495.

Carter, J.R., \& Irons, M.D. (1991). Are economists different, and if so, why? Journal of Economic Perspectives, 5(2): 171-177

Dutta, P. (1999). Strategies and Games: Theory and Practice. Cambridge, MA: The MIT Press.

Fischbacher, U. (2007). Z-Tree: Zurich toolbox for ready-made economic experiments. Experimental Economics, 10(2): 171-178.

Frank, R.H., Gilovich, T., \& Regan, D.T. (1993). Does studying economics inhibit cooperation? Journal of Economic Perspectives, 7(2): 159-171.

Frank, R.H., Bernanke, B., Antonovics, K., \& Heffetz, O. (2015). Principles of Economics, $6^{\text {th }}$ ed. New York: McGraw Hill Education. 
Frank, B., \& Schulze, G.G. (2000) Does economics make citizens corrupt? Journal of Economic Behavior and Organization, 43(1): 101-113.

Frey, B.S., \& Meier, S. (2003). Are political economists selfish and indoctrinated? Evidence from a natural experiment. Economic Inquiry, 41(3): 448-462.

Gandal, N., Roccas, S., Sagiv, L., \& Wrzesniewski, A. (2005). Personal value priorities of economists. Human Relations, 58(10): 1227-1252.

Konow, J. (2003). Which Is the Fairest One of All? A Positive Analysis of Justice Theories. Journal of Economic Literature, 41(4): 1188-1239.

Krugman, P., \& Wells, R. (2015). Economics, $4^{\text {th }}$ ed. New York: Worth Publishers.

Mankiw, N.G. (2015). Principles of Economics, $7^{\text {th }}$ ed. Stamford, CT: Cengage Learning.

Marwell, G., \& Ames, R.E. (1981). Economists free ride, does anyone else? Journal of Public Economics, 15(3): 295-310.

Raskin, R.N., \& Hall, C.S. (1979). A narcissistic personality inventory. Psychological Reports, 45 (2): 590.

Rose, P. (2007). Mediators of the association between narcissism and compulsive buying: The roles of materialism and impulse control. Psychology of Addictive Behaviors, 21(4): 576-581.

Siegfried, J.J., \& Walstad, W.B. (2014). Undergraduate coursework in economics: A survey perspective. Journal of Economic Education, 45(2): 147-158.

Snyder, T.D., de Brey, C., and Dillow, S.A. (2016). Digest of Education Statistics 2014 (NCES 2016-006). National Center for Education Statistics, Institute of Education Sciences, U.S. Department of Education. Washington, DC. 
von Hippel, W., Lakin, J. L., \& Shakarchi, R. J. (2005). Individual differences in motivated social cognition: The case of self-serving information processing. Personality and Social Psychology Bulletin, 31, 1347-1357.

Wang, L., Malhotra, D., \& Murnighan, J.K. (2011). Economics education and greed. Academy of Management Learning \& Education, 10(4): 643-660.

Yezer, A.M., Goldfarb, R.S., \& Poppen, P.J. (1996). Does studying economics discourage competition? Watch what we do, not what we say or how we play. Journal of Economic Perspectives, 10(1): 177-186. 
Table 1. UG proposer offers, normative treatment versus control

\begin{tabular}{ccccccc} 
& $\begin{array}{c}\text { Pre- } \\
\text { lesson } \\
(1)\end{array}$ & $\begin{array}{c}\text { Post- } \\
\text { lesson } \\
(2)\end{array}$ & $\begin{array}{c}\text { Change } \\
(3)\end{array}$ & $\begin{array}{c}\text { Proportion } \\
\text { decrease } \\
(4)\end{array}$ & $\begin{array}{c}\text { Proportion } \\
\text { increase } \\
(5)\end{array}$ & $\begin{array}{c}\text { Change }^{\wedge} \\
(6)\end{array}$ \\
\hline Normative & $\$ 8.76$ & $\$ 4.70$ & $-\$ 4.06$ & 0.67 & 0.02 & $-\$ 4.22$ \\
$n=87$ & $(\$ 0.40)$ & $(\$ 0.43)$ & $(\$ 0.43)$ & $(0.05)$ & $(0.02)$ & $(\$ 0.53)$ \\
Control & $\$ 8.37$ & $\$ 7.76$ & $-\$ 0.61$ & 0.22 & 0.19 & $-\$ 0.56$ \\
$n=100$ & $(\$ 0.37)$ & $(\$ 0.35)$ & $(\$ 0.39)$ & $(0.04)$ & $(0.04)$ & $(\$ 0.32)$ \\
\hline Difference & $\$ 0.39$ & $\mathbf{- \$ 3 . 0 6}$ & $\mathbf{- \$ 3 . 4 5}$ & $\mathbf{0 . 4 5}$ & $\mathbf{- 0 . 1 7}$ & $\mathbf{- \$ 3 . 6 6}$ \\
& $(\$ 0.54)$ & $(\$ 0.56)$ & $(\$ 0.58)$ & $(0.07)$ & $(0.04)$ & $(\$ 0.62)$ \\
& $\{0.473\}$ & $\{0.000\}$ & $\{0.000\}$ & $\{0.000\}$ & $\{0.000\}$ & $\{0.000\}$ \\
\hline
\end{tabular}

UG proposer offers can range from $\$ 1$ to $\$ 20$. Column (1) represents mean offers in Task 1. Column (2) represents mean offers in Task 7. Columns (4) and (5) represent the proportion of subjects for whom Task-7 offers are lower and higher than Task-1 offers, respectively. Column (6) recalculates Column (3) restricting to subjects who correctly answered all UG-comprehension questions (normative $\mathrm{n}=60$; control $\mathrm{n}=59$ ). Standard error in parenthesis. $\mathrm{p}$-value for difference of means between treatment and control group in brackets (two-tailed $t$ test). Bold indicates statistical significance at 0.05 level; bold italics indicate statistical significance at the 0.01 level. 
Table 2. UG responder minimum accepted offers, normative treatment versus control

\begin{tabular}{ccccccc} 
& $\begin{array}{c}\text { Pre- } \\
\text { lesson } \\
(1)\end{array}$ & $\begin{array}{c}\text { Post- } \\
\text { lesson } \\
(2)\end{array}$ & $\begin{array}{c}\text { Change } \\
(3)\end{array}$ & $\begin{array}{c}\text { Proportion } \\
\text { decrease } \\
(4)\end{array}$ & $\begin{array}{c}\text { Proportion } \\
\text { increase } \\
(5)\end{array}$ & $\begin{array}{c}\text { Change }^{\wedge} \\
(6)\end{array}$ \\
\hline Normative & $\$ 4.37$ & $\$ 2.65$ & $-\$ 1.90$ & 0.42 & 0.07 & $-\$ 2.11$ \\
$\mathrm{n}=81$ & $(\$ 0.39)$ & $(\$ 0.32)$ & $(\$ 0.37)$ & $(0.06)$ & $(0.03)$ & $(\$ 0.45)$ \\
Control & $\$ 4.69$ & $\$ 4.01$ & $-\$ 0.72$ & 0.18 & 0.11 & $-\$ 0.61$ \\
$\mathrm{n}=95$ & $(\$ 0.41)$ & $(\$ 0.37)$ & $(\$ 0.32)$ & $(0.04)$ & $(0.03)$ & $(\$ 0.32)$ \\
\hline Difference & $\mathbf{\$ 0 . 3 2}$ & $\mathbf{- \$ 1 . 3 6}$ & $\mathbf{- \$ 1 . 1 9}$ & $\mathbf{0 . 2 4}$ & -0.03 & $\mathbf{- \$ 1 . 4 9}$ \\
& $(\$ 0.57)$ & $(\$ 0.49)$ & $(\$ 0.49)$ & $(0.07)$ & $(0.04)$ & $(\$ 0.56)$ \\
& $\{0.582\}$ & $\{0.007\}$ & $\{0.016\}$ & $\{0.000\}$ & $0.476\}$ & $0.009\}$ \\
\hline
\end{tabular}

UG responder minimum accepted offers can range from $\$ 1$ to $\$ 20$. Column (1) represents mean minimum accepted offers in Task 2. Column (2) represents mean minimum accepted offers in Task 8. Columns (4) and (5) represent the proportion of subjects for whom Task- 8 minimum accepted offers are lower and higher than Task-2 offers, respectively. Column (6) recalculates Column (3) restricting to subjects who correctly answered all UG-comprehension questions (normative $n=57$; control $n=57$ ). Standard error in parenthesis. p-value for difference of means between treatment and control group in brackets (two-tailed $t$ test). Bold indicates statistical significance at 0.05 level; bold italics indicate statistical significance at the 0.01 level. 
Table 3. PD defection rates, normative treatment versus control

\begin{tabular}{ccccc} 
& $\begin{array}{c}\text { Pre- } \\
\text { lesson } \\
(1)\end{array}$ & $\begin{array}{c}\text { Post- } \\
\text { lesson } \\
(2)\end{array}$ & $\begin{array}{c}\text { Change } \\
(3)\end{array}$ & $\begin{array}{c}\text { Change }^{\wedge} \\
(4)\end{array}$ \\
\hline Normative & 0.59 & 0.82 & 0.23 & 0.25 \\
$\mathrm{n}=87$ & $(0.05)$ & $(0.04)$ & $(0.05)$ & $(0.06)$ \\
Control & 0.63 & 0.74 & 0.11 & 0.09 \\
$\mathrm{n}=100$ & $(0.05)$ & $(0.04)$ & $(0.04)$ & $(0.04)$ \\
\hline Difference & -0.04 & 0.08 & 0.12 & $\mathbf{0 . 1 6}$ \\
& $(0.07)$ & $(0.06)$ & $(0.06)$ & $(0.07)$ \\
& $\{0.543\}$ & $\{0.216\}$ & $\{0.055\}$ & $\{0.015\}$ \\
\hline
\end{tabular}

Column (1) represents mean defection rates in Task 6. Column (2) represents mean defection rates in Task 12. Column (4) recalculates Column (3) restricting to subjects who correctly answered all PDcomprehension questions (normative $n=71$; control $n=88$ ). Standard error in parenthesis. p-value for difference of means between treatment and control group in brackets (two-tailed $t$ test). Bold indicates statistical significance at 0.05 level; bold italics indicate statistical significance at the 0.01 level. 
Table 4. DG divisions, normative treatment versus control

\begin{tabular}{ccccccc} 
& $\begin{array}{c}\text { Pre- } \\
\text { lesson } \\
(1)\end{array}$ & $\begin{array}{c}\text { Post- } \\
\text { lesson } \\
(2)\end{array}$ & $\begin{array}{c}\text { Change } \\
(3)\end{array}$ & $\begin{array}{c}\text { Proportion } \\
\text { decrease } \\
(4)\end{array}$ & $\begin{array}{c}\text { Proportion } \\
\text { increase } \\
(5)\end{array}$ & $\begin{array}{c}\text { Change }^{\wedge} \\
(6)\end{array}$ \\
\hline Normative & $\$ 4.89$ & $\$ 3.10$ & $-\$ 1.78$ & 0.45 & 0.10 & $-\$ 1.81$ \\
$\mathrm{n}=87$ & $(\$ 0.48)$ & $(\$ 0.43)$ & $(\$ 0.40)$ & $(0.05)$ & $(0.03)$ & $(\$ 0.42)$ \\
Control & $\$ 5.07$ & $\$ 4.72$ & $-\$ 0.35$ & 0.24 & 0.18 & $-\$ 0.28$ \\
$\mathrm{n}=100$ & $(\$ 0.47)$ & $(\$ 0.49)$ & $(\$ 0.31)$ & $(0.04)$ & $(0.04)$ & $(\$ 0.34)$ \\
\hline Difference & $\mathbf{- \$ 0 . 1 8}$ & $\mathbf{- \$ 1 . 6 2}$ & $\mathbf{- \$ 1 . 4 3}$ & $\mathbf{0 . 2 1}$ & -0.08 & $\mathbf{- \$ 1 . 5 3}$ \\
& $(\$ 0.67)$ & $(\$ 0.66)$ & $(\$ 0.50)$ & $(0.07)$ & $(0.05)$ & $(\$ 0.53)$ \\
& $\{0.783\}$ & $\{0.016\}$ & $\{0.005\}$ & $\{0.003\}$ & $\{0.139\}$ & $\{0.005\}$ \\
\hline
\end{tabular}

DG divisions can range from $\$ 0$ to $\$ 20$. Column (1) represents mean divisions in Task 3. Column (2) represents mean divisions in Task 9. Columns (4) and (5) represent the proportion of subjects for whom Task-9 divisions are lower and higher than Task-3 divisions, respectively. Column (6) recalculates Column (3) restricting to subjects who correctly answered all DG-comprehension questions (normative $\mathrm{n}=83$; control $\mathrm{n}=89$ ). Standard error in parenthesis. $\mathrm{p}$-value for difference of means between treatment and control group in brackets (two-tailed $t$ test). Bold indicates statistical significance at 0.05 level; bold italics indicate statistical significance at the 0.01 level. 
Table 5. PGG contributions, normative treatment versus control

\begin{tabular}{ccccccc} 
& $\begin{array}{c}\text { Pre- } \\
\text { lesson } \\
(1)\end{array}$ & $\begin{array}{c}\text { Post- } \\
\text { lesson } \\
(2)\end{array}$ & $\begin{array}{c}\text { Change } \\
(3)\end{array}$ & $\begin{array}{c}\text { Proportion } \\
\text { decrease } \\
(4)\end{array}$ & $\begin{array}{c}\text { Proportion } \\
\text { increase } \\
(5)\end{array}$ & $\begin{array}{c}\text { Change }^{\wedge} \\
(6)\end{array}$ \\
\hline Normative & $\$ 6.99$ & $\$ 5.99$ & $-\$ 1.00$ & 0.28 & 0.20 & $-\$ 1.05$ \\
$\mathrm{n}=87$ & $(\$ 0.64)$ & $(\$ 0.67)$ & $(\$ 0.47)$ & $(0.05)$ & $(0.04)$ & $(\$ 0.44)$ \\
Control & $\$ 6.83$ & $\$ 6.45$ & $-\$ 0.38$ & 0.24 & 0.19 & $-\$ 0.09$ \\
$\mathrm{n}=100$ & $(\$ 0.63)$ & $(\$ 0.64)$ & $(\$ 0.35)$ & $(0.04)$ & $(0.04)$ & $(\$ 0.37)$ \\
\hline Difference & $\$ 0.16$ & $-\$ 0.46$ & $-\$ 0.62$ & 0.04 & 0.01 & $-\$ 0.96$ \\
& $(\$ 0.90)$ & $(\$ 0.93)$ & $(\$ 0.58)$ & $(0.06)$ & $(0.06)$ & $(\$ 0.57)$ \\
& $\{0.860\}$ & $\{0.620\}$ & $\{0.287\}$ & $\{0.578\}$ & $\{0.926\}$ & $\{0.094\}$ \\
\hline
\end{tabular}

PGG contributions can range from $\$ 0$ to $\$ 20$. Column (1) represents mean contributions in Task 5.

Column (2) represents mean contributions in Task 11. Columns (4) and (5) represent the proportion of subjects for whom Task- 11 contributions are lower and higher than Task- 5 contributions, respectively. Column (6) recalculates Column (3) restricting to subjects who correctly answered all PGG-

comprehension questions (normative $\mathrm{n}=76$; control $\mathrm{n}=87$ ). Standard error in parenthesis. $\mathrm{p}$-value for difference of means between treatment and control group in brackets (two-tailed $t$ test). Bold indicates statistical significance at 0.05 level; bold italics indicate statistical significance at the 0.01 level. 
Table 6. UG proposer offers, positive treatment versus control

\begin{tabular}{ccccccc} 
& $\begin{array}{c}\text { Pre- } \\
\text { lesson } \\
(1)\end{array}$ & $\begin{array}{c}\text { Post- } \\
\text { lesson } \\
(2)\end{array}$ & $\begin{array}{c}\text { Change } \\
(3)\end{array}$ & $\begin{array}{c}\text { Proportion } \\
\text { decrease } \\
(4)\end{array}$ & $\begin{array}{c}\text { Proportion } \\
\text { increase } \\
(5)\end{array}$ & $\begin{array}{c}\text { Change^ } \\
(6)\end{array}$ \\
\hline Positive & $\$ 8.09$ & $\$ 7.83$ & $-\$ 0.26$ & 0.28 & 0.24 & $-\$ 0.10$ \\
$\mathrm{n}=89$ & $(\$ 0.37)$ & $(\$ 0.33)$ & $(\$ 0.27)$ & $(0.05)$ & $(0.05)$ & $(\$ 0.31)$ \\
Control & $\$ 8.37$ & $\$ 7.76$ & $-\$ 0.61$ & 0.22 & 0.19 & $-\$ 0.56$ \\
$\mathrm{n}=100$ & $(\$ 0.37)$ & $(\$ 0.35)$ & $(\$ 0.39)$ & $(0.04)$ & $(0.04)$ & $(\$ 0.32)$ \\
\hline Difference & $-\$ 0.28$ & $\$ 0.07$ & $\$ 0.35$ & 0.06 & 0.05 & $\$ 0.46$ \\
& $(\$ 0.52)$ & $(\$ 0.49)$ & $(\$ 0.49)$ & $(0.06)$ & $(0.06)$ & $(\$ 0.44)$ \\
& $\{0.594\}$ & $\{0.884\}$ & $\{0.470\}$ & $\{0.336\}$ & $\{0.443\}$ & $\{0.299\}$ \\
\hline
\end{tabular}

UG proposer offers can range from $\$ 1$ to $\$ 20$. Column (1) represents mean offers in Task 1. Column (2) represents mean offers in Task 7. Columns (4) and (5) represent the proportion of subjects for whom Task-7 offers are lower and higher than Task-1 offers, respectively. Column (6) recalculates Column (3) restricting to subjects who correctly answered all UG-comprehension questions (normative $\mathrm{n}=62$; control $\mathrm{n}=59$ ). Standard error in parenthesis. $\mathrm{p}$-value for difference of means between treatment and control group in brackets (two-tailed $t$ test). Bold indicates statistical significance at 0.05 level; bold italics indicate statistical significance at the 0.01 level. 
Table 7. UG responder minimum accepted offers, positive treatment versus control

\begin{tabular}{ccccccc} 
& $\begin{array}{c}\text { Pre- } \\
\text { lesson } \\
(1)\end{array}$ & $\begin{array}{c}\text { Post- } \\
\text { lesson } \\
(2)\end{array}$ & $\begin{array}{c}\text { Change } \\
(3)\end{array}$ & $\begin{array}{c}\text { Proportion } \\
\text { decrease } \\
(4)\end{array}$ & $\begin{array}{c}\text { Proportion } \\
\text { increase } \\
(5)\end{array}$ & $\begin{array}{c}\text { Change }^{\wedge} \\
(6)\end{array}$ \\
\hline Positive & $\$ 4.03$ & $\$ 4.30$ & $\$ 0.17$ & 0.21 & 0.25 & $\$ 0.55$ \\
$\mathrm{n}=87$ & $\$ 0.38)$ & $(\$ 0.36)$ & $(\$ 0.31)$ & $(0.04)$ & $(0.05)$ & $(\$ 0.36)$ \\
Control & $\$ 4.69$ & $\$ 4.01$ & $-\$ 0.72$ & 0.18 & 0.11 & $-\$ 0.61$ \\
$\mathrm{n}=95$ & $(\$ 0.41)$ & $(\$ 0.37)$ & $(\$ 0.32)$ & $(0.04)$ & $(0.03)$ & $(\$ 0.32)$ \\
\hline Difference & $-\$ 0.65$ & $\$ 0.29$ & $\mathbf{\$ 0 . 8 9}$ & 0.03 & $\mathbf{0 . 1 5}$ & $\$ \mathbf{1 . 1 6}$ \\
& $(\$ 0.57)$ & $(\$ 0.52)$ & $(\$ 0.45)$ & $(0.06)$ & $(0.06)$ & $(\$ 0.49)$ \\
& $\{0.250\}$ & $\{0.574\}$ & $\{0.049\}$ & $\{0.635\}$ & $\{0.009\}$ & $0.019\}$ \\
\hline
\end{tabular}

UG responder minimum accepted offers can range from $\$ 1$ to $\$ 20$. Column (1) represents mean minimum accepted offers in Task 2. Column (2) represents mean minimum accepted offers in Task 8. Columns (4) and (5) represent the proportion of subjects for whom Task- 8 minimum accepted offers are lower and higher than Task-2 offers, respectively. Column (6) recalculates Column (3) restricting to subjects who correctly answered all UG-comprehension questions (normative $n=61$; control $n=57$ ). Standard error in parenthesis. p-value for difference of means between treatment and control group in brackets (two-tailed $t$ test). Bold indicates statistical significance at 0.05 level; bold italics indicate statistical significance at the 0.01 level. 
Table 8. PD defection rates, positive treatment versus control

\begin{tabular}{ccccc} 
& $\begin{array}{c}\text { Pre- } \\
\text { lesson } \\
(1)\end{array}$ & $\begin{array}{c}\text { Post- } \\
\text { lesson } \\
(2)\end{array}$ & $\begin{array}{c}\text { Change } \\
(3)\end{array}$ & $\begin{array}{c}\text { Change }^{\wedge} \\
(4)\end{array}$ \\
\hline Positive & 0.57 & 0.73 & 0.16 & 0.15 \\
$\mathrm{n}=89$ & $(0.05)$ & $(0.05)$ & $(0.05)$ & $(0.05)$ \\
Control & 0.63 & 0.74 & 0.11 & 0.09 \\
$\mathrm{n}=100$ & $(0.05)$ & $(0.04)$ & $(0.04)$ & $(0.04)$ \\
\hline Difference & -0.06 & -0.01 & 0.05 & 0.06 \\
& $(0.07)$ & $(0.06)$ & $(0.06)$ & $(0.06)$ \\
& $\{0.427\}$ & $\{0.881\}$ & $\{0.431\}$ & $\{0.348\}$ \\
\hline
\end{tabular}

Column (1) represents mean defection rates in Task 6. Column (2) represents mean defection rates in Task 12. Column (4) recalculates Column (3) restricting to subjects who correctly answered all PDcomprehension questions (normative $n=80$; control $n=88$ ). Standard error in parenthesis. p-value for difference of means between treatment and control group in brackets (two-tailed $t$ test). Bold indicates statistical significance at 0.05 level; bold italics indicate statistical significance at the 0.01 level. 
Table 9. DG divisions, positive treatment versus control

\begin{tabular}{ccccccc} 
& $\begin{array}{c}\text { Pre- } \\
\text { lesson } \\
(1)\end{array}$ & $\begin{array}{c}\text { Post- } \\
\text { lesson } \\
(2)\end{array}$ & $\begin{array}{c}\text { Change } \\
(3)\end{array}$ & $\begin{array}{c}\text { Proportion } \\
\text { decrease } \\
(4)\end{array}$ & $\begin{array}{c}\text { Proportion } \\
\text { increase } \\
(5)\end{array}$ & $\begin{array}{c}\text { Change }^{\wedge} \\
(6)\end{array}$ \\
\hline Positive & $\$ 5.36$ & $\$ 5.61$ & $\$ 0.25$ & 0.25 & 0.25 & $\$ 0.12$ \\
$n=89$ & $\$ 0.46)$ & $(\$ 0.43)$ & $(\$ 0.37)$ & $(0.05)$ & $(0.05)$ & $(\$ 0.38)$ \\
Control & $\$ 5.07$ & $\$ 4.72$ & $-\$ 0.35$ & 0.24 & 0.18 & $-\$ 0.28$ \\
$n=100$ & $(\$ 0.47)$ & $(\$ 0.49)$ & $(\$ 0.31)$ & $(0.04)$ & $(0.04)$ & $(\$ 0.34)$ \\
\hline Difference & $\$ 0.29$ & $\$ 0.89$ & $\$ 0.60$ & 0.01 & 0.07 & $\$ 0.40$ \\
& $(\$ 0.66)$ & $(\$ 0.66)$ & $(\$ 0.48)$ & $(0.06)$ & $(0.06)$ & $(\$ 0.51)$ \\
& $\{0.661\}$ & $\{0.181\}$ & $\{0.216\}$ & $\{0.909\}$ & $\{0.261\}$ & $\{0.429\}$ \\
\hline
\end{tabular}

DG divisions can range from $\$ 0$ to $\$ 20$. Column (1) represents mean divisions in Task 3. Column (2) represents mean divisions in Task 9. Columns (4) and (5) represent the proportion of subjects for whom Task-9 divisions are lower and higher than Task-3 divisions, respectively. Column (6) recalculates Column (3) restricting to subjects who correctly answered all DG-comprehension questions (normative $n=82$; control $n=89$ ). Standard error in parenthesis. p-value for difference of means between treatment and control group in brackets (two-tailed $t$ test). Bold indicates statistical significance at 0.05 level; bold italics indicate statistical significance at the 0.01 level. 
Table 10. PGG contributions, positive treatment versus control

\begin{tabular}{ccccccc} 
& $\begin{array}{c}\text { Pre- } \\
\text { lesson } \\
(1)\end{array}$ & $\begin{array}{c}\text { Post- } \\
\text { lesson } \\
(2)\end{array}$ & $\begin{array}{c}\text { Change } \\
(3)\end{array}$ & $\begin{array}{c}\text { Proportion } \\
\text { decrease } \\
(4)\end{array}$ & $\begin{array}{c}\text { Proportion } \\
\text { increase } \\
(5)\end{array}$ & $\begin{array}{c}\text { Change }^{\wedge} \\
(6)\end{array}$ \\
\hline Positive & $\$ 6.99$ & $\$ 7.39$ & $\$ 0.40$ & 0.18 & 0.30 & $\$ 0.28$ \\
$\mathrm{n}=89$ & $(\$ 0.60)$ & $(\$ 0.63)$ & $(\$ 0.35)$ & $(0.04)$ & $(0.05)$ & $(\$ 0.38)$ \\
Control & $\$ 6.83$ & $\$ 6.45$ & $-\$ 0.38$ & 0.24 & 0.19 & $-\$ 0.09$ \\
$\mathrm{n}=100$ & $(\$ 0.63)$ & $(\$ 0.64)$ & $(\$ 0.35)$ & $(0.04)$ & $(0.04)$ & $(\$ 0.37)$ \\
\hline Difference & $\$ 0.16$ & $\$ 0.94$ & $\$ 0.78$ & -0.06 & 0.11 & $\$ 0.37$ \\
& $(\$ 0.87)$ & $(\$ 0.90)$ & $(\$ 0.50)$ & $(0.06)$ & $(0.06)$ & $(\$ 0.53)$ \\
& $\{0.856\}$ & $\{0.298\}$ & $\{0.118\}$ & $\{0.314\}$ & $\{0.071\}$ & $\{0.486\}$ \\
\hline
\end{tabular}

PGG contributions can range from $\$ 0$ to $\$ 20$. Column (1) represents mean contributions in Task 5.

Column (2) represents mean contributions in Task 11. Columns (4) and (5) represent the proportion of subjects for whom Task-11 contributions are lower and higher than Task- 5 contributions, respectively. Column (6) recalculates Column (3) restricting to subjects who correctly answered all PGGcomprehension questions (normative $n=75$; control $n=87$ ). Standard error in parenthesis. $p$-value for difference of means between treatment and control group in brackets (two-tailed $t$ test). Bold indicates statistical significance at $0.05 \mathrm{level}$; bold italics indicate statistical significance at the 0.01 level. 
Table 11. Pre-lesson decisions, by prior game theory

\begin{tabular}{|c|c|c|c|c|c|c|}
\hline & $\begin{array}{l}\text { UG offer } \\
\text { (1) }\end{array}$ & $\begin{array}{l}\text { UG min } \\
\text { accept } \\
\text { offer } \\
(2)\end{array}$ & $\begin{array}{c}\text { PD } \\
\text { defection } \\
(3)\end{array}$ & $\begin{array}{c}\mathrm{DG} \\
\text { divisions } \\
(4)\end{array}$ & $\begin{array}{c}\text { PGG } \\
\text { contribution } \\
\text { (5) }\end{array}$ & $\begin{array}{c}\text { SCU Fund } \\
\text { contributio } \\
\mathrm{n} \\
(6)\end{array}$ \\
\hline $\begin{array}{l}\text { Prior game theory } \\
\quad \mathrm{n}=72\end{array}$ & $\begin{array}{l}\$ 7.04 \\
(\$ 0.48)\end{array}$ & $\begin{array}{l}\$ 3.72 \\
(\$ 0.44)\end{array}$ & $\begin{array}{l}0.71 \\
(0.05)\end{array}$ & $\begin{array}{l}\$ 3.72 \\
(\$ 0.45)\end{array}$ & $\begin{array}{l}\$ 6.26 \\
(\$ 0.76)\end{array}$ & $\begin{array}{l}\$ 1.11 \\
(\$ 0.16)\end{array}$ \\
\hline $\begin{array}{l}\text { No prior game } \\
\text { theory } \\
\quad n=204\end{array}$ & $\begin{array}{l}\$ 8.88 \\
(\$ 0.23)\end{array}$ & $\begin{array}{l}\$ 4.61 \\
(\$ 0.27)\end{array}$ & $\begin{array}{l}0.56 \\
(0.03)\end{array}$ & $\begin{array}{l}\$ 5.59 \\
(\$ 0.32)\end{array}$ & $\begin{array}{l}\$ 7.17 \\
(\$ 0.41)\end{array}$ & $\begin{array}{l}\$ 1.50 \\
(\$ 0.11)\end{array}$ \\
\hline Difference & $\begin{array}{l}-\$ 1.84 \\
(\$ 0.49) \\
\{0.000\}\end{array}$ & $\begin{array}{l}-\$ 0.88 \\
(\$ 0.52) \\
\{0.091\}\end{array}$ & $\begin{array}{c}\mathbf{0 . 1 5} \\
(0.07) \\
\{0.026\}\end{array}$ & $\begin{array}{l}-\$ 1.87 \\
(\$ 0.61) \\
\{0.002\}\end{array}$ & $\begin{array}{l}-\$ 0.90 \\
(\$ 0.82) \\
\{0.270\}\end{array}$ & $\begin{array}{l}-\$ 0.39 \\
(\$ 0.20) \\
\{0.053\}\end{array}$ \\
\hline
\end{tabular}

UG offers and minimum accepted offers can range from $\$ 1$ to $\$ 20$. DG divisions and PGG contributions can range from $\$ 0$ to $\$ 20$. SCU contributions can range from $\$ 0$ to $\$ 5$. Standard error in parenthesis. $p$-value for difference of means between treatment and control group in brackets (two-tailed $t$ test). Bold indicates statistical significance at 0.05 level; bold italics indicate statistical significance at the 0.01 level. Note: the number of observations for the first and second rows of column (2) are 69 and 195, respectively. 
Table 12. Pre-lesson decisions, by prior SCU economics course(s) taken

\begin{tabular}{lcccccc} 
& $\begin{array}{c}\text { UG min } \\
\text { accept } \\
\text { offer } \\
(1)\end{array}$ & $\begin{array}{c}\text { PD } \\
\text { defection } \\
(2)\end{array}$ & $\begin{array}{c}\text { DG } \\
\text { divisions } \\
(4)\end{array}$ & $\begin{array}{c}\text { PGG } \\
\text { contribution } \\
(5)\end{array}$ & $\begin{array}{c}\text { SCU Fund } \\
\text { contribution } \\
(6)\end{array}$ \\
\hline $\begin{array}{l}\text { Taken econ } \\
\text { course(s) }\end{array}$ & $\$ 8.37$ & $\$ 4.48$ & 0.71 & $\$ 4.21$ & $\$ 5.80$ & $\$ 0.87$ \\
$\quad \mathrm{n}=100$ & $(\$ 0.38)$ & $(\$ 0.39)$ & $(0.05)$ & $(\$ 0.41)$ & $(\$ 0.53)$ & $(\$ 0.11)$ \\
No econ course & $\$ 8.42$ & $\$ 4.31$ & 0.53 & $\$ 5.61$ & $\$ 7.57$ & $\$ 1.70$ \\
$\quad \mathrm{n}=176$ & $(\$ 0.26)$ & $(\$ 0.28)$ & $(0.04)$ & $(\$ 0.35)$ & $(\$ 0.47)$ & $(\$ 0.12)$ \\
\hline Difference & $-\$ 0.05$ & $-\$ 0.17$ & $\mathbf{0 . 1 8}$ & $\mathbf{- \$ 1 . 4 0}$ & $\mathbf{- \$ 1 . 7 7}$ & $\mathbf{- \$ 0 . 8 3}$ \\
& $(\$ 0.45)$ & $(\$ 0.48)$ & $(0.06)$ & $(\$ 0.56)$ & $(\$ 0.74)$ & $(\$ 0.18)$ \\
& $\{0.912\}$ & $\{0.716\}$ & $\{0.004\}$ & $\{0.012\}$ & $\{0.017\}$ & $\{0.000\}$ \\
\hline
\end{tabular}

UG offers and minimum accepted offers can range from $\$ 1$ to $\$ 20$. DG divisions and PGG contributions can range from $\$ 0$ to $\$ 20$. SCU contributions can range from $\$ 0$ to $\$ 5$. Standard error in parenthesis. $p$-value for difference of means between treatment and control group in brackets (two-tailed $t$ test). Bold indicates statistical significance at 0.05 level; bold italics indicate statistical significance at the 0.01 level. Note: the number of observations for the first and second rows of column (2) are 97 and 167, respectively. 
Table 13. Normative-treatment training effects, by prior exposure to economics instruction

\begin{tabular}{|c|c|c|c|c|c|}
\hline & $\begin{array}{c}\text { UG offer } \\
\text { (1) }\end{array}$ & $\begin{array}{l}\text { UG min } \\
\text { accept } \\
\text { offer } \\
(2)\end{array}$ & $\begin{array}{c}\text { PD } \\
\text { defection } \\
(3)\end{array}$ & $\begin{array}{c}\text { DG } \\
\text { divisions } \\
(4)\end{array}$ & $\begin{array}{c}\text { PGG } \\
\text { contribution } \\
\text { (5) }\end{array}$ \\
\hline \multicolumn{6}{|l|}{ Change } \\
\hline \multicolumn{6}{|l|}{ Prior econ } \\
\hline $\begin{array}{l}\text { exposure } \\
\mathrm{n}=43\end{array}$ & $(\$ 0.62)$ & $(\$ 0.59)$ & $(0.07)$ & $(\$ 0.46)$ & $(\$ 0.61)$ \\
\hline \multirow{2}{*}{$\begin{array}{l}\text { No prior exposure } \\
\qquad \mathrm{n}=44\end{array}$} & $-\$ 3.48$ & $-\$ 0.97$ & 0.23 & $-\$ 1.93$ & $-\$ 1.16$ \\
\hline & $(\$ 0.60)$ & $(\$ 0.42)$ & $(0.08)$ & $(\$ 0.65)$ & $(\$ 0.72)$ \\
\hline \multirow[t]{3}{*}{ Difference } & $-\$ 1.17$ & $-\$ 1.79$ & 0.01 & $\$ 0.30$ & $\$ 0.32$ \\
\hline & $(\$ 0.86)$ & $(\$ 0.73)$ & $(0.10)$ & $(\$ 0.80)$ & $(\$ 0.95)$ \\
\hline & $\{0.176\}$ & $\{0.016\}$ & $\{0.959\}$ & $\{0.706\}$ & $\{0.736\}$ \\
\hline \multicolumn{6}{|l|}{ Post-lesson } \\
\hline $\begin{array}{l}\text { exposure } \\
\mathrm{n}=43\end{array}$ & $\begin{array}{l}\$ 3.95 \\
(\$ 0.51)\end{array}$ & $\begin{array}{l}\$ 1.95 \\
(\$ 0.30)\end{array}$ & $\begin{array}{l}0.93 \\
(0.04)\end{array}$ & $\begin{array}{l}\$ 2.26 \\
(\$ 0.49)\end{array}$ & $\begin{array}{l}\$ 5.47 \\
(\$ 1.01)\end{array}$ \\
\hline \multirow{2}{*}{$\begin{array}{l}\text { No prior exposure } \\
\qquad \mathrm{n}=44\end{array}$} & $\$ 5.43$ & $\$ 3.35$ & 0.70 & $\$ 3.93$ & $\$ 6.50$ \\
\hline & $(\$ 0.69)$ & $(\$ 0.54)$ & $(0.07)$ & $(\$ 0.68)$ & $(\$ 0.90)$ \\
\hline \multirow[t]{3}{*}{ Difference } & $-\$ 1.48$ & $-\$ 1.40$ & 0.23 & $-\$ 1.68$ & $-\$ 1.03$ \\
\hline & $(\$ 0.86)$ & $(\$ 0.62)$ & $(0.08)$ & $(\$ 0.84)$ & $(\$ 1.35)$ \\
\hline & $\{0.089\}$ & $\{0.027\}$ & $\{0.006\}$ & $\{0.050\}$ & $\{0.444\}$ \\
\hline
\end{tabular}

UG offers and minimum accepted offers can range from $\$ 1$ to $\$ 20$. DG divisions and PGG contributions can range from $\$ 0$ to $\$ 20$. Standard error in parenthesis. $p$-value for difference of means between treatment and control group in brackets (two-tailed $t$ test). Bold indicates statistical significance at 0.05 level; bold italics indicate statistical significance at the 0.01 level. Note: the number of observations for the first and second rows of column (2) are 42 and 39 , respectively. 
Table 14. Pre-lesson decisions and normative-treatment training effects, by donation to SCU fund

\begin{tabular}{|c|c|c|c|c|c|}
\hline & $\begin{array}{c}\text { UG offer } \\
(1)\end{array}$ & $\begin{array}{l}\text { UG min } \\
\text { accept } \\
\text { offer } \\
(2)\end{array}$ & $\begin{array}{c}\text { PD } \\
\text { defection } \\
(3) \\
\end{array}$ & $\begin{array}{c}\mathrm{DG} \\
\text { division } \\
(4)\end{array}$ & $\begin{array}{c}\text { PGG } \\
\text { contribution } \\
(5)\end{array}$ \\
\hline \multicolumn{6}{|l|}{ Pre-lesson } \\
\hline \multirow{2}{*}{$\begin{array}{l}\$ 2-5 \text { to SCU fund } \\
\quad \mathrm{n}=106\end{array}$} & $\$ 9.43$ & $\$ 4.18$ & 0.43 & $\$ 7.16$ & $\$ 9.40$ \\
\hline & $(\$ 0.33)$ & $(\$ 0.35)$ & $(0.05)$ & $(\$ 0.41)$ & $(\$ 0.59)$ \\
\hline \multirow{2}{*}{$\begin{array}{l}\$ 0 \text { to SCU fund } \\
\qquad \mathrm{n}=99\end{array}$} & $\$ 7.66$ & $\$ 4.46$ & 0.76 & $\$ 3.08$ & $\$ 4.46$ \\
\hline & $(\$ 0.39)$ & $(\$ 0.39)$ & $(0.04)$ & $(\$ 0.40)$ & $(\$ 0.58)$ \\
\hline \multirow[t]{3}{*}{ Difference } & $\$ 1.78$ & $-\$ 0.28$ & -0.32 & $\$ 4.08$ & $\$ 4.93$ \\
\hline & $(\$ 0.51)$ & $(\$ 0.53)$ & $(0.06)$ & $(\$ 0.58)$ & $(\$ 0.82)$ \\
\hline & $\{0.001\}$ & $\{0.590\}$ & $\{0.000\}$ & $\{0.000\}$ & $\{0.000\}$ \\
\hline \multicolumn{6}{|c|}{ Change (normative only) } \\
\hline \multirow{2}{*}{$\begin{array}{l}\$ 2-5 \text { to SCU fund } \\
\qquad \mathrm{n}=33\end{array}$} & $-\$ 4.97$ & $-\$ 2.09$ & 0.30 & $-\$ 2.94$ & $-\$ 1.52$ \\
\hline & $(\$ 0.76)$ & $(\$ 0.69)$ & $(0.09)$ & $(\$ 0.62)$ & $(\$ 0.62)$ \\
\hline \multirow{2}{*}{$\begin{array}{l}\$ 0 \text { to SCU fund } \\
\qquad \mathrm{n}=31\end{array}$} & $-\$ 3.03$ & $-\$ 1.64$ & 0.26 & $-\$ 0.71$ & $-\$ 0.84$ \\
\hline & $(\$ 0.60)$ & $(\$ 0.49)$ & $(0.09)$ & $(\$ 0.73)$ & $(\$ 0.83)$ \\
\hline \multirow[t]{3}{*}{ Difference } & $-\$ 1.94$ & $-\$ 0.45$ & 0.04 & $-\$ 2.23$ & $-\$ 0.68$ \\
\hline & $(\$ 0.98)$ & $(\$ 0.87)$ & $(0.13)$ & $(\$ 0.95)$ & $(\$ 1.03)$ \\
\hline & $\{0.052\}$ & $\{0.606\}$ & $\{0.732\}$ & $\{0.022\}$ & $\{0.514\}$ \\
\hline \multicolumn{6}{|c|}{$\begin{array}{l}\text { UG offers and minimum accepted offers can range from } \$ 1 \text { to } \$ 20 \text {. DG divisions and PGG } \\
\text { contributions can range from } \$ 0 \text { to } \$ 20 \text {. Standard error in parenthesis. p-value for difference of means } \\
\text { between treatment and control group in brackets (two-tailed } t \text { test). Bold indicates statistical significance } \\
\text { at } 0.05 \text { level; bold italics indicate statistical significance at the } 0.01 \text { level. Note: the number of } \$ 2-5 \text { and } \\
\$ 0 \text { donations to the SCU fund pre-lesson observations for column (2) are } 101 \text { and } 95 \text {, respectively; the } \\
\text { number of } \$ 2-5 \text { and } \$ 0 \text { donations to the SCU fund "change" observations for column (2) are } 32 \text { and } 28 \text {, } \\
\text { respectively. }\end{array}$} \\
\hline
\end{tabular}


Table 15. Pre-lesson decisions and normative-treatment training effects, by narcissism

\begin{tabular}{|c|c|c|c|c|c|c|}
\hline & $\begin{array}{c}\text { UG offer } \\
\text { (1) }\end{array}$ & $\begin{array}{l}\text { UG min } \\
\text { accept } \\
\text { offer } \\
(2)\end{array}$ & $\begin{array}{c}\text { PD } \\
\text { defection } \\
\text { (3) }\end{array}$ & $\begin{array}{c}\text { DG } \\
\text { division } \\
\text { (4) }\end{array}$ & $\begin{array}{c}\text { PGG } \\
\text { contribution } \\
\text { (5) }\end{array}$ & $\begin{array}{l}\text { SCU Fund } \\
\text { contribution } \\
\text { (6) }\end{array}$ \\
\hline \multicolumn{7}{|l|}{ Pre-lesson } \\
\hline \multirow{2}{*}{$\begin{array}{l}\text { High narcissism } \\
\quad \mathrm{n}=122\end{array}$} & $\$ 7.70$ & $\$ 4.25$ & 0.66 & $\$ 4.91$ & $\$ 6.48$ & $\$ 1.20$ \\
\hline & $(\$ 0.34)$ & $(\$ 0.33)$ & $(0.04)$ & $(\$ 0.42)$ & $(\$ 0.51)$ & $(\$ 0.12)$ \\
\hline \multirow{2}{*}{$\begin{array}{l}\text { Low narcissism } \\
\qquad \mathrm{n}=115\end{array}$} & $\$ 8.99$ & $\$ 4.42$ & 0.50 & $\$ 5.63$ & $\$ 7.70$ & $\$ 1.63$ \\
\hline & $(\$ 0.32)$ & $(\$ 0.37)$ & $(0.05)$ & $(\$ 0.41)$ & $(\$ 0.58)$ & $(\$ 0.15)$ \\
\hline \multirow[t]{3}{*}{ Difference } & $-\$ 1.29$ & $-\$ 0.18$ & 0.16 & $-\$ 0.72$ & $-\$ 1.22$ & $-\$ 0.42$ \\
\hline & $(\$ 0.47)$ & $(\$ 0.49)$ & $(0.06)$ & $(\$ 0.58)$ & $(\$ 0.77)$ & $(\$ 0.19)$ \\
\hline & $\{0.006\}$ & $\{0.721\}$ & $\{0.013\}$ & $\{0.222\}$ & $\{0.115\}$ & $\{0.030\}$ \\
\hline \multicolumn{7}{|c|}{ Change (normative only) } \\
\hline \multirow{2}{*}{$\begin{array}{l}\text { High narcissism } \\
\quad \mathrm{n}=44\end{array}$} & $-\$ 3.95$ & $-\$ 1.74$ & 0.18 & $-\$ 1.66$ & $-\$ 1.23$ & \\
\hline & $(\$ 0.60)$ & $(\$ 0.51)$ & $(0.06)$ & $(\$ 0.58)$ & $(\$ 0.55)$ & \\
\hline \multirow{2}{*}{$\begin{array}{l}\text { Low narcissism } \\
\qquad \mathrm{n}=38\end{array}$} & $-\$ 4.11$ & $-\$ 1.92$ & 0.37 & $-\$ 2.13$ & $-\$ 0.76$ & \\
\hline & $(\$ 0.70)$ & $(\$ 0.57)$ & $(0.08)$ & $(\$ 0.62)$ & $(\$ 0.87)$ & \\
\hline \multirow[t]{3}{*}{ Difference } & $\$ 0.15$ & $\$ 0.18$ & -0.19 & $\$ 0.47$ & $-\$ 0.46$ & \\
\hline & $(\$ 0.92)$ & $(\$ 0.76)$ & $(0.10)$ & $(\$ 0.85)$ & $(\$ 1.01)$ & \\
\hline & $\{0.870\}$ & $\{0.816\}$ & $\{0.058\}$ & $\{0.578\}$ & $\{0.646\}$ & \\
\hline
\end{tabular}

UG offers and minimum accepted offers can range from $\$ 1$ to $\$ 20$. DG divisions and PGG contributions can range from $\$ 0$ to $\$ 20$. SCU contributions can range from $\$ 0$ to $\$ 5$. Standard error in parenthesis. $p$-value for difference of means between treatment and control group in brackets (two-tailed $t$ test). Bold indicates statistical significance at 0.05 level; bold italics indicate statistical significance at the 0.01 level. Note: the number of high- and low-narcissism prelesson observations for column (2) are 118 and 109, respectively; the number of high-and low-narcissism "change" observations for column (2) are 42 and 36 , respectively. 
Table 16. UG efficiency and equity, normative treatment versus control

\begin{tabular}{lcccccc} 
& $\begin{array}{c}\text { Pre- } \\
\text { lesson } \\
\text { efficiency } \\
(1)\end{array}$ & $\begin{array}{c}\text { Post- } \\
\text { lesson } \\
\text { efficiency } \\
(2)\end{array}$ & $\begin{array}{c}\text { Post- } \\
\text { lesson } \\
\text { proposer } \\
\text { payment } \\
(3)\end{array}$ & $\begin{array}{c}\text { Post- } \\
\text { lesson } \\
\text { responder } \\
\text { payment } \\
(4)\end{array}$ & $\begin{array}{c}\text { Pre- } \\
\text { lesson } \\
\text { Gini } \\
\text { index } \\
(5)\end{array}$ & $\begin{array}{c}\text { Post- } \\
\text { lesson } \\
\text { Gini- } \\
\text { index } \\
(6)\end{array}$ \\
\hline $\begin{array}{l}\text { Normativ } \\
\text { e } \quad \mathrm{n}=87\end{array}$ & 0.82 & 0.66 & $\$ 9.46$ & $\$ 3.64$ & 0.31 & 0.56 \\
Control & $(0.04)$ & $(0.05)$ & $(\$ 0.81)$ & $(\$ 0.44)$ & $(0.03)$ & $(0.03)$ \\
\multicolumn{1}{c}{$\mathrm{n}=100$} & 0.87 & 0.85 & $\$ 9.73$ & $\$ 7.27$ & 0.26 & 0.29 \\
\hline $\begin{array}{l}\text { Differenc } \\
\text { e }\end{array}$ & $(0.03)$ & $(0.04)$ & $(\$ 0.50)$ & $(\$ 0.42)$ & $(0.02)$ & $(0.03)$ \\
& -0.05 & $\mathbf{- 0 . 1 9}$ & $-\$ 0.27$ & $\mathbf{- \$ 3 . 6 3}$ & 0.05 & $\mathbf{0 . 2 7}$ \\
& $(0.05)$ & $(0.06)$ & $(\$ 0.93)$ & $(\$ 0.61)$ & $(0.03)$ & $(0.04)$ \\
& $\{0.312\}$ & $\{0.002\}$ & $\{0.771\}$ & $\{0.000\}$ & $\{0.177\}$ & $\{0.000\}$ \\
\hline
\end{tabular}

Columns (1) and (2) represent the proportion of Task-1 and Task-7 offers accepted, respectively.

Columns (3) and (4) represent mean payments received by proposers and responders, conditional on offer acceptance, respectively. Bootstrapped standard error in parenthesis (100 repetitions). p-value for difference of means between treatment and control group in brackets (two-tailed $t$ test). Bold indicates statistical significance at 0.05 level; bold italics indicate statistical significance at the 0.01 level. 
Figure 1a. Pre- and post-lesson UG offers, normative treatment

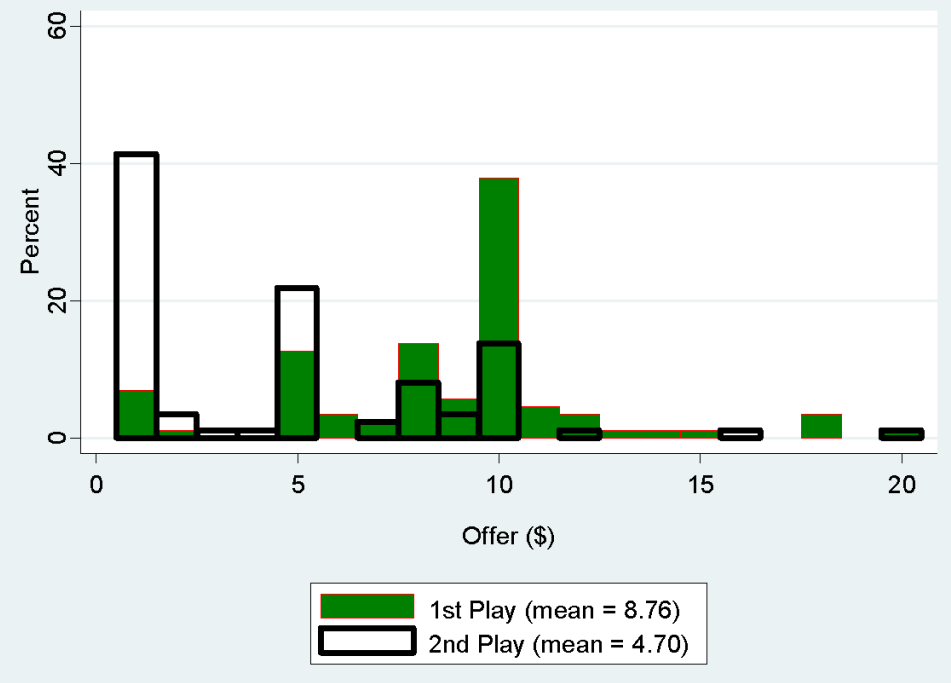

Figure 1b. Pre- and post-lesson offers, control

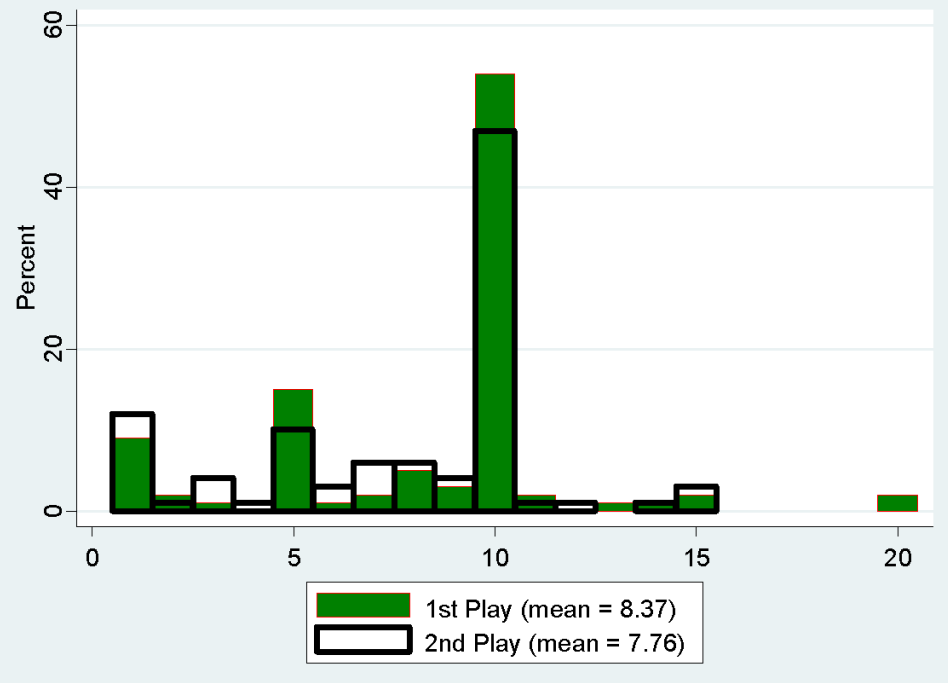


Figure 2a. UG post-lesson Lorenz curve, normative treatment versus control

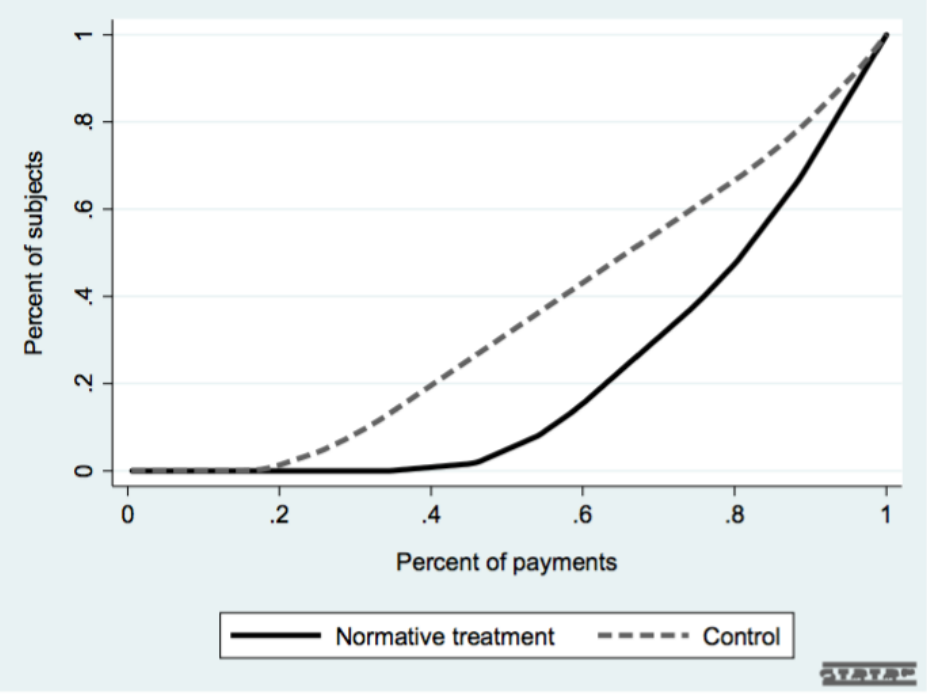

Figure 2 b. UG pre-lesson Lorenz curve, normative treatment versus control

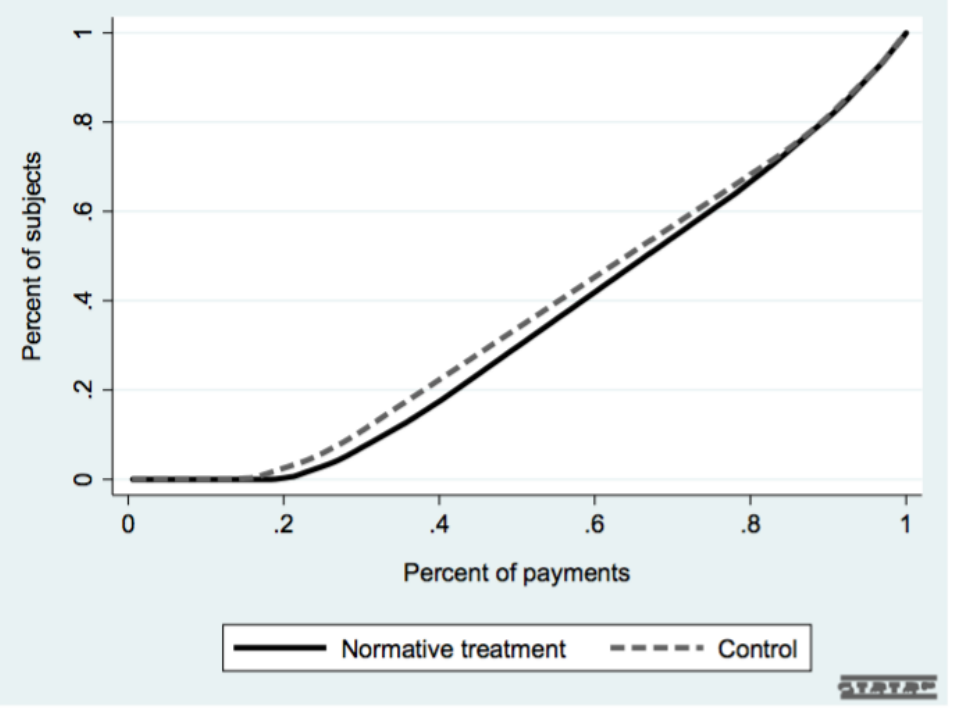

